\title{
ASSESMENT OF GROWTH AND PRODUCTIVITY OF CUCUMBER (CUCUMIS SATIVUS L.) GENOTYPES UNDER SALT STRESS REGIME
}

\author{
SARWAR, M..$^{{ }^{*}}$ - AhMAD, S. ${ }^{1}-$ CHATTHA, M. B. ${ }^{1}-$ CHATTHA, M. U. ${ }^{2}-$ AlAM, M. W. $.^{1}-$ \\ ANJUM, S. $^{3}$ - ShAFEEQ, T. ${ }^{1}-$ NASEEM, M. K. ${ }^{1}$ - MANNAN, A. ${ }^{1}$ \\ ${ }^{1}$ Institute of Agricultural Sciences, University of the Punjab (Quaid-e-azam campus) \\ Lahore, Pakistan \\ ${ }^{2}$ Depatment of Agronomy, Bahauddin Zakariya University, Multan, Pakistan \\ ${ }^{3}$ Depatment of Botany, University of Agriculture, Faisalabad, Pakistan \\ *Corresponding author \\ e-mail:mubeensarwar4@yahoo.com,mubeen.iags@pu.edu.pk \\ (Received $8^{\text {th }}$ Mar 2019; accepted $3^{\text {rd }}$ May 2019)
}

\begin{abstract}
The potential of cucumber (Cucumis sativus L.) genotypes for salt tolerance was investigated in a pot experiment under a lath house conditions. Salt stress substantially reduced plant growth and physiological traits in cucumber plants. On other hand, increase in accumulation of organic solutes i.e., proline as well as activity of anti-oxidant enzymes like SOD, POD and CAT were also observed. However, salinity also caused ionic imbalancement in studied genotypes and lead towards high leaf sodium and chloride $\left(\mathrm{Na}^{+}, \mathrm{Cl}\right)$ content along with a significant reduction in leaf $\mathrm{K}^{+}$and $\mathrm{Ca}^{+}$levels. On the behalf of percent increment or reduction in observed, cucumber genotypes Marketmore \& Green long were found to be salt resistant, while Summer green and 20252 catagerized as salt sensitive. Tolerant genotypes effectively maintained better dry biomass and high $\mathrm{Ca}^{+}$and $\mathrm{K}^{+}$content with least $\mathrm{Na}^{+}$and $\mathrm{Cl}^{-}$ in their leaves exposed to salt stress. Furthermore, maximum accumulation of proline contents and greater activity of antioxidants (SOD, POD and CAT) results in improved tolerance under salinity which indicate that salt tolerance induced in cucumber is greatly connected with level of organic osmolytes and antioxidant defense system.
\end{abstract}

Keywords: photosynthesis, salinity tolerance, glycinbetaine, salinity stress, superoxide dismutase, peroxidase

\section{Introduction}

Increasing salinity is threat for vegetable production, particularly in irrigated areas where $40 \%$ food of the world's is produce (Sarwar et al., 2016, 2017). Some vegetables i.e., onions, cucumbers, tomatoes, peppers and eggplants are sensitive to salinity (Yamaguchi and Blumwald, 2005; Sarwar et al., 2017). Stepien and Klobus (2006) and Sarwar et al. (2018) stated that cucumber considered is an important vegetable for human nutrition and diet and it is source of vitamins and dietary fiber; it has been used for 3,000 years in its native areas of Asia and Africa (Gopalan et al., 1982). But melicious impact of salt stress on cucumber crop caused a severe reduction in crop growth and yield (El-shraiy et al., 2011; Sarwar et al., 2016, 2017). Cucumber growth significantly affected by salinity higher than $25 \mathrm{mM}$, which caused a reduction in yield upto 13\% (Chartzoulzkis, 1992; Dorota, 1997). Soil salinity is a very serious threat being faced by agriculture sector of the world as it restricts the plant growth and yield (Qin et al., 2010; Mahboob et al., 2017; Sarwar et al., 2017) modulates leaf gas 
exchange traits (Maeda and Nakazawa, 2008) enhanced cell membranes leakage (Dogan et al., 2010) and caused nutrient deficiency (Yang et al., 2008).

Salt stress resistance in plants depends on types of salts which are present in soil, plant growth conditions, genotype, age and management practice (Sheekh-El et al., 2002; Ashraf et al., 2010) it prompts osmotic and ionic stress which affect the morphophysio and biochemical modifications at cellular level (Murphy and Durako, 2003). Higher amount of salts in soil, reduced the water potential of plant cell and soil which restrict the plant roots to absorb necessary water (Lloyd et al., 1989) that lead dehydration and ultimately cause death of the cell. Soil salinity means $\mathrm{Na}^{+}$and $\mathrm{Cl}^{-}$ions are dominant and higher level of such ions leads to ionic toxicity in salt sensitive crops (Garcia-Sanchez et al., 2002). Maximum amount of toxic ions in saline environment inhibits absorption of the essential nutrients i.e., $\mathrm{K}^{+}, \mathrm{Ca}^{+}$and $\mathrm{Mg}^{+}$(Hasegawa et al., 2000) and moreover enhance the concentrations of toxic ions $\mathrm{Na}^{+}$or $\mathrm{Cl}^{-}$in plant cells which results in enhanced permeability and/or destabilization of cellular membranes by subsituting $\mathrm{Ca}^{+}$and $\mathrm{K}^{+}$(Grattan and Grieve, 1992). Photosynthetic activity of plant decreased due to modulation in stomatal conductance under salinity (Sarwar et al., 2017). Loss of turgor by osmotic effect of salinity resulted in stomata will close, reduce the supply of carbon dioxide to leaves of plants. Though, in calvin cycle more reduction in photosynthetic rate was also reported due to degradation of green pigments; decreased leaf area by reducing photosynthetic enzyme activity (Misra et al., 1997; Ashraf et al., 2010). Salinity-induced oxidative stress has toxic reactions like, mutation, degradation of protein and lipid peroxidation that impaired photosynthesis (Mccord, 2000). Salinty and drought tolerance mechanism in plants comprises balance between osmotic adjustment, ions concentrations, osmotic adjustment is a water balance in cell due to accumulation of proline, sugars and their role as an osmolyte for osmotic adjustment. Sugars alcohols i.e. mannitol and sorbitol, and glycinebetaines are bring into mainly protect the protein of cytoplasm or keep away cell membranes desiccation (Ashraf et al., 2010; Balal et al., 2012).

Keeping in view the malicious impact of salt stress on plants, the objectives of our study were to figure out the physiological, biochemical and chemical responses of cucumber genotypes on scientific basis for elucidating the fundamental mechanisms involved in salt tolerance. Such information is also key for suggesting a suitable crop cultivar for salt-affected soils. Furthermore objective of this study was to determine the fluctuations in ionic homeostasis of cucumber genotypes in response to Nacl salinity.

\section{Material and methods}

Current investigation was planned to find out the potential of cucumber genotypes for their salt tolerance under lath house conditions $\left(30-35^{\circ} \mathrm{C}\right.$ and relative humidity 40-50\%) in University of Agriculture, Faisalabad- Pakistan. Four contrasting cucumber genotypes (Marketmore, Green long, Summer green and 20252) have varying degree of salinity tolerance were used for this study. A sand culture experiment was comprised with seven treatments and replicated four times, every treatment contain 12 pots; so, total 84 pots were used for this study. Before start of experiment, seeds of uniform size and identical color were selected and sterilized by using $3 \%$ solution (v/v) of sodium hypo-chlorite for ten minutes. Distilled water was used to rinsed the seeds and air-dried the seeds at $25^{\circ} \mathrm{C}$. Eight cucumber seeds were sown in each $9 \mathrm{~L}$ plastic pot, after one week of emergence, thinning was carried out to maintain four plants in each pot. Plants 
were irrigated after two days interval, half strength Hogland solution was used as a nutrient source twice in a week. Salt stress was based on Nacl (MERCK, CAS \#-764714-5), $\mathrm{NaCl}$ stress was imposed at 40 days old crop after sowing. Six levels of salinity were investigated i.e., (Control- no stress), 2, 3, 4, 5, 6 and $7 \mathrm{dS} \mathrm{m}^{-1} \mathrm{NaCl}$. To avoid the osmotic shock, salt stress was imposed by gradual increments untill final concentrations reached for each treatments. The levels of salinity were maintained through out the experiment by recording $\mathrm{EC}$ and $\mathrm{pH}$ of the growing media. After one weeks of $\mathrm{NaCl}$ induction data were recorded for evaluation.

\section{Growth characteristics}

Five plants selected from each treatment to calculate the morphological traits, e.g. shoot/root length of cucumber plants with meter rod. Fresh weight of both shoot/root was weighed by an electrical balance $(\mathrm{g})$. For dry weight determination these shoot/root were placed in oven at $70^{\circ} \mathrm{C}$ temperature for 72 hours and mean values were calculated.

\section{Leaf gas exchange attributes}

The gaseous characteristics were estimated with Infrared Gas Analyzer by the described method of Sarwar et al. (2017).

\section{Chlorophyll contents (SPAD)}

For each plant, quantification of chlorophyll were taken from fully expanded third to forth young leave (Khan et al., 2003).

\section{Membrane leakage (\%)}

Membrane leakage was assessed by the procedure of Lutts et al. (1996). Ten leaf discs of approximately same size were selected from young fully expanded leaf. After washing to remove dirt from leaf, little leaf discs were dipped in test tube having $10 \mathrm{ml}$ distilled water and these tubes leave for 24 hour under room temperature followed by the determination of $\left(\mathrm{EC}_{1}\right)$ of electrolyte rich solution with the help of $\mathrm{EC}$ meter. Later on, the samples were shifted to water bath at $72^{\circ} \mathrm{C}$ for 20 minutes and subsequently cooled at room temperature. The $\mathrm{EC}$ of diffused tissues $\left(\mathrm{EC}_{2}\right)$ was recorded. Membrane leakage was deliberated as ratio between $\mathrm{EC}_{1}$ and $\mathrm{EC}_{2}$ and expressed into \%age.

\section{Antioxidant enzymes and proline contents}

Superoxide dismutase activity was assessed via proposed procedure of (Giannopolitis and Ries, 1977). Catalase and peroxidase were determined by the method of Chance and Maehly (1955). Whereas proline and glycinebetaine were quantified by the techniques of Bates et al. (1973) and Grieve and Gratan (1983).

\section{Determination of ionic content $\left(\mathrm{Na}^{+}, \mathrm{K}^{+}\right.$and $\left.\mathrm{Ca}^{+}\right)$}

The concentrtion of sodium, potassium and calcium were quantify according to method of digested leave samples The content of $\mathrm{Na}^{+}$and $\mathrm{K}^{+}$in extracted solution was estimated by flame photometer (Model Jenway PFP-7; UK). A graded series of standards (ranging from 10- $100 \mathrm{mg} \mathrm{L}^{-1}$ ) of $\mathrm{Na}^{+} \mathrm{K}^{+}$and $\mathrm{Ca}^{+}$were prepared to draw standard curves used to quantify final concentration. 


\section{Determination of Chloride}

For determination of chloride ions, grounded plant material (1 gram) was taken in $50 \mathrm{ml}$ test tube having $20 \mathrm{ml}$ of distilled water and heated in an oven for overnight at $66^{\circ} \mathrm{C}$. Then this solution filtered with "Whatmann-40 filter paper" and quantify of content with the help of $\mathrm{Cl}^{-}$analyzer (Model: Corning-920, Germany).

\section{Statistical analysis}

The collected data was statistically analyzed under Completely Randomize Design (CRD) with factorial arrangement using (ANOVA) analysis of variance technique by Statistix 8.1 by implying HSD (Tukey's Test).

\section{Results}

\section{Plant growth attributes}

The present results revealed that increasing salt stress significantly and gradually reduced plant biomass in response of shoot/root length, fresh/dry weight and no. of leaves per plant. However, this decline was minimum in Marketmore, Green long genotypes who maintained better shootand root length, fresh and dry biomass by retaining maximum no. of leaves/plant as comparison to Summer green or 20252 genotypes (Figs. 1, 2, 3a).
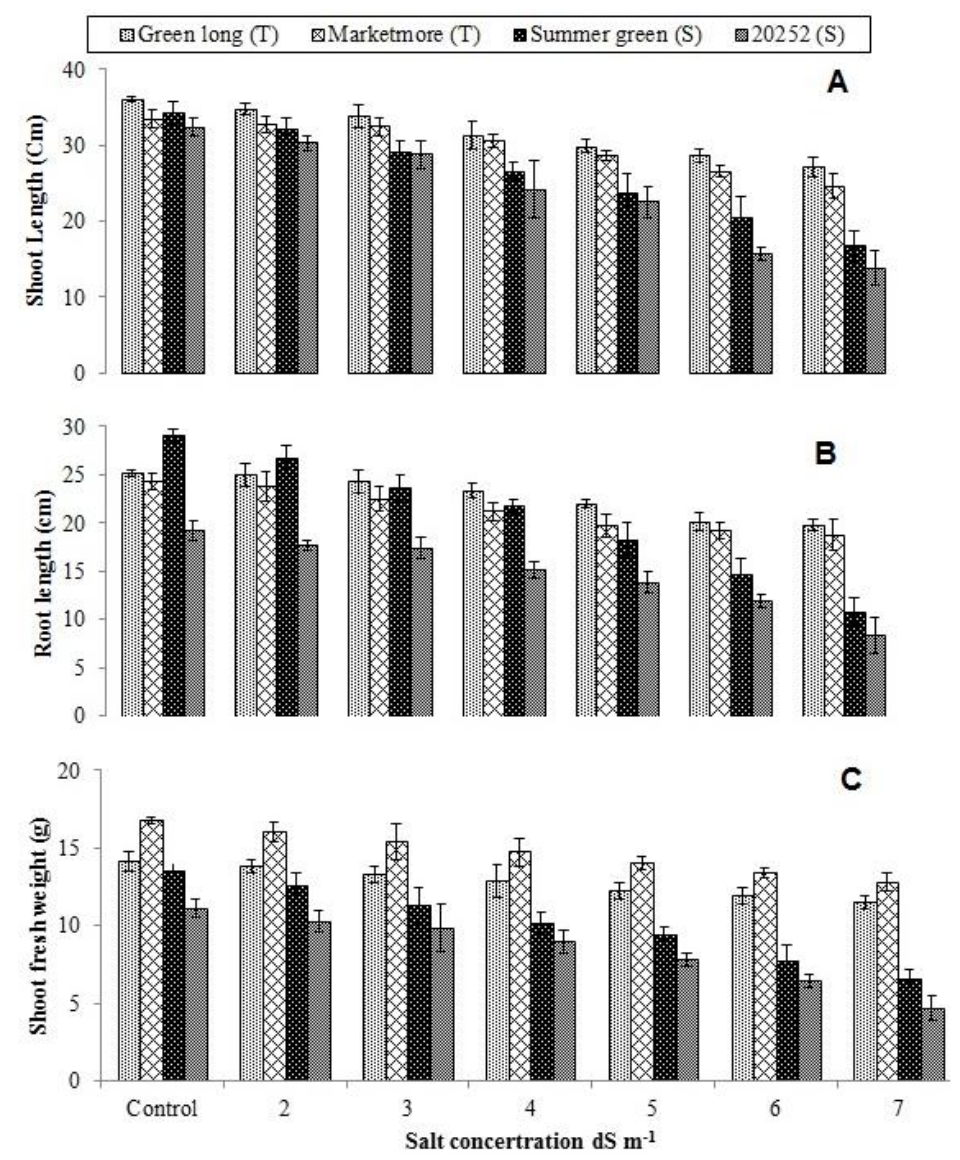

Figure 1. Effect of salt stress on (a) shoot length (b) root length (c) Shoot fresh weight $(g)$ 
Among the genotypes, Greenlong effectively neutralized the negative impects of salinity on plant growth and performed better than other genotypes under all salinity treatments. Hence, maximum shoot fresh weight was exhibited by market more under all experimental conditions. Cucumber 20252 showed maximum sensitivity towards salinity at all concentrations of salt stress and failed to manage considerable no. of leaves which produced lower shoot/root lengths with minimum fresh/dry weights.
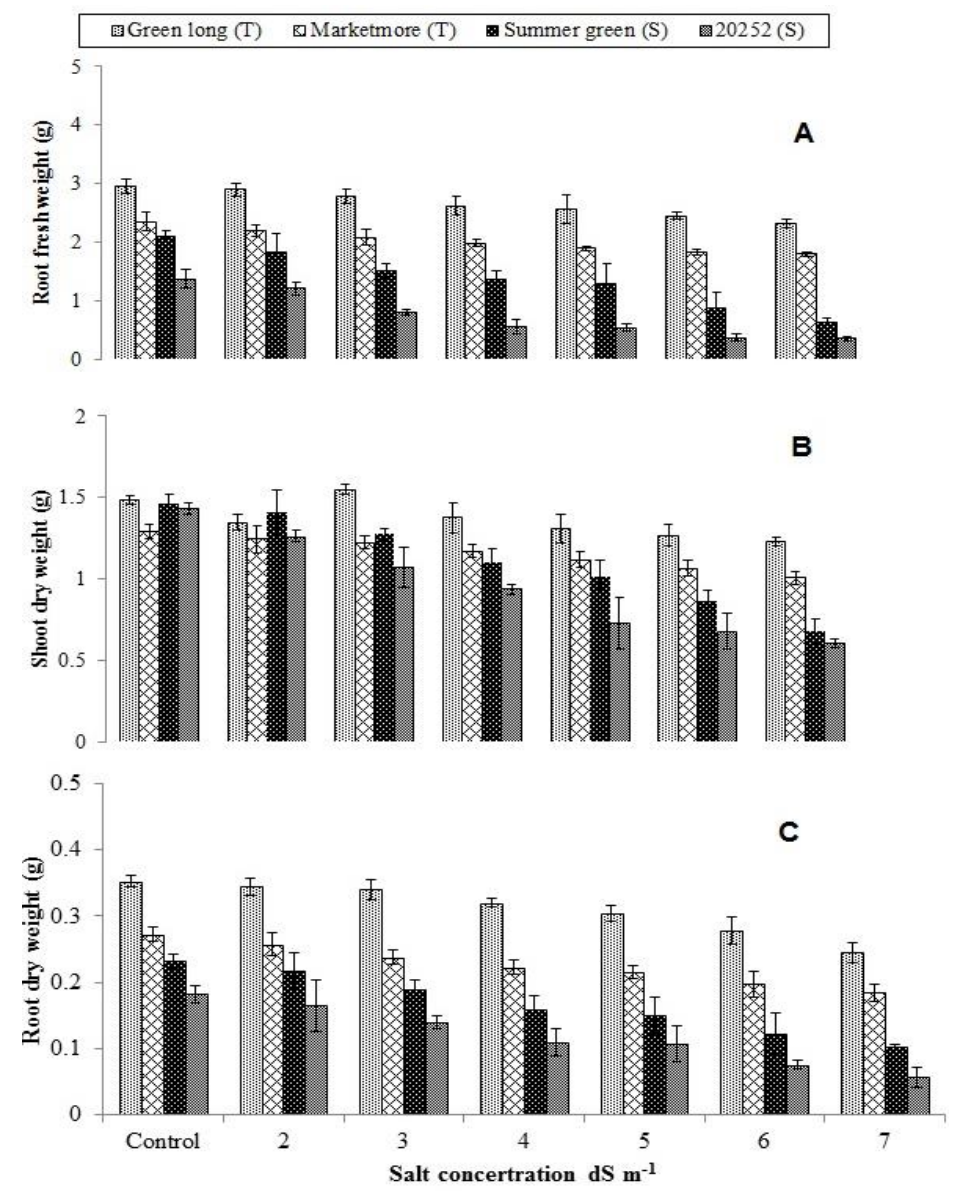

Figure 2. Effect of salt stress on (a) Root fresh weight (b) Shoot dry weight (c) Root dry weight

\section{Leaf gas exchange attributes and chlorophyll content (SPAD)}

Gas exchange attributes meaningfully decreased in tested cucumber genotypes (Fig. 3) at all salt levels however, significant decline in photosynthesis was induced by $6 \mathrm{dS} \mathrm{m}^{-1}$ salinity (Fig. 3b,c). Under highest salt level $7.0 \mathrm{dS} \mathrm{m}^{-1}$, maximum reduction in gas exchange attributes were noted for Summer green or 20252 whereas, lowest for Marketmore or Green long in comparison to their controls. Increasing salt level caused decline in gas exchange attributes in tested genotypes, but higher decreased in these parameters was noted for genotype 20252 which is followed by Summer green. Maximum photosynthetic and respiration rate was exhibited by Marketmore under all salinity levels that is statistically at par with green long and behaved alike. Whereas, genotype 20252 showed highest stomatal conductance up to $3 \mathrm{dS} \mathrm{m}^{-1}$ salt stress but Green long maintained better stomatal conductance and improved water use efficiency even at higher level of salinity which is followed by Marketmore. Likewise, all the 
evaluating genotypes illustrate significant degradation of leaf chlorophyll in answer to elevating salt stress (Fig 4 c). Maximum decline was observed at $7 \mathrm{dSm}^{-1}$. Thus, Green long and marketmore produced maximum chlorophyll under all level of salinity which expressed their capacity to tolerate salinity stress. Contrarly, high levels of salinity significantly affected stay green ability of Summer green and 20252 by reducing chlorophyll pigment. Lowest chlorophyll content was recorded for same genotypes at highest stress of $7 \mathrm{dSm}^{-1}$.
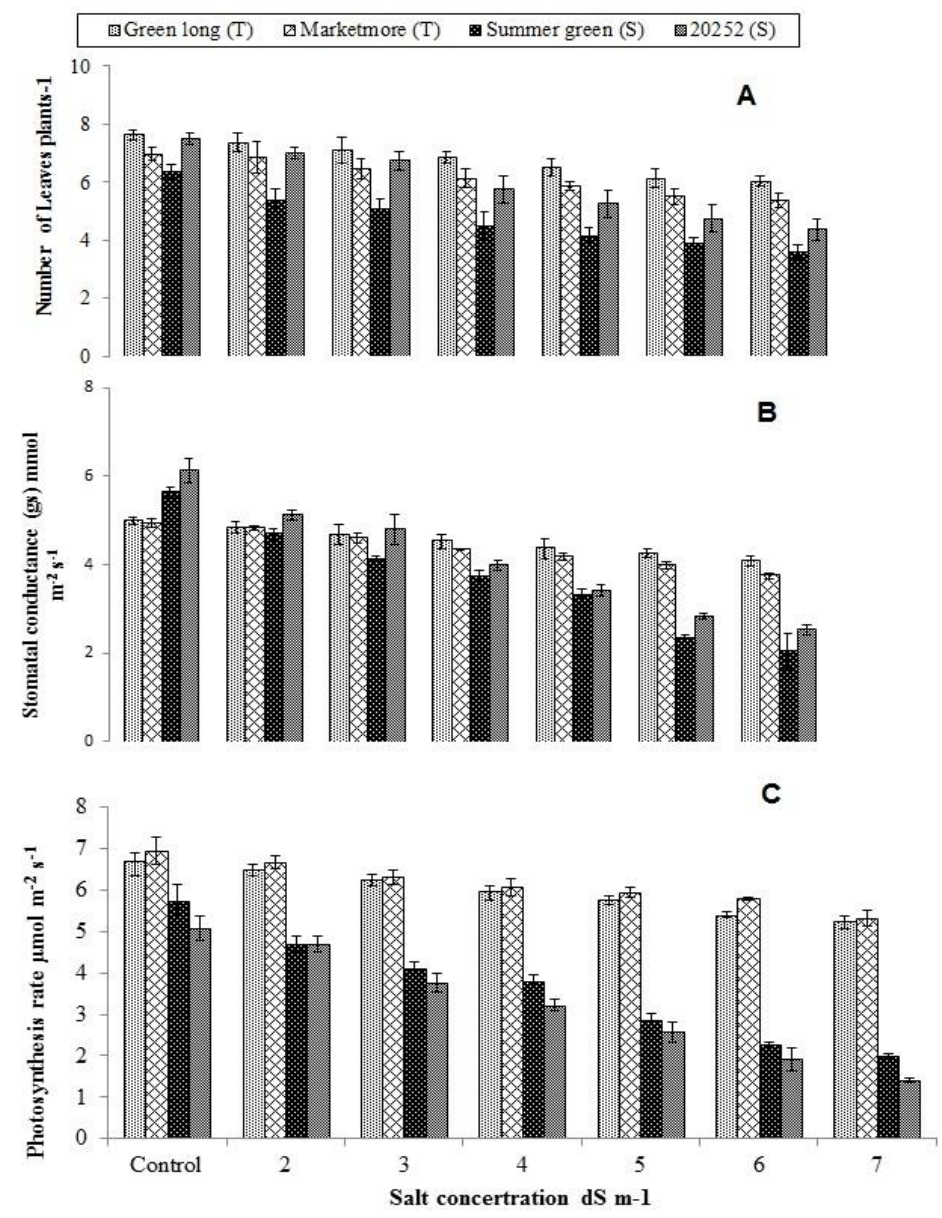

Figure 3. Effect of salt stress on (a) number of leaves plant $^{-1}$ (b) Stomatal conductance (c) Photosynthesis rate

\section{Electrolyte leakage(\%)}

It is obvious from data that all the cucumber genotypes showed a significant enhancement in electrolyte leakage when subjected to salt stress. Hence, the gradual increase in electrolyte leakage was observed with rising level of salinity and maximum increase was noted at $7 \mathrm{dSm}^{-1}$ stress in genotype (20252) that was statistically at par with Summer green and behaved alike. Among the genotypes, Marketmore and Green long maintained better membrane stability and resulted in minimum electrolyte leakage under all salinity treatments over non-saline control. It indicates that electrolyte leakage $\%$ that can be used as potential approach for evaluating salt stress tolerance in cucumber plants. 


\section{Antioxidant enzymes and osmolytes}

It is clear from presented data that imposition of different salts concentration had a significant impact on the production of proline content and enzymatic activities in tested cucumber genotypes (Fig. 5b,c). However, maximum accumulation of proline and antioxidant activity was observed at highest saline level $\left(7 \mathrm{dSm}^{-1}\right)$. In case of genotypes, highest activities of CAT, SOD, POD and proline was demonstrated by Marketmore that was proceeded by green long genotype on exposure to all salinity treatments. Whereas, summer green was unable to produce better proline content as presented in Fig. 6 and releaved minimum values for proline at all stress levels. Likewise, lowest activities of SOD, CAT, POD antioxidant were also exhibited by summer green as compared to other genotypes uder control and salt stress as well (Figs. 5 and 6).

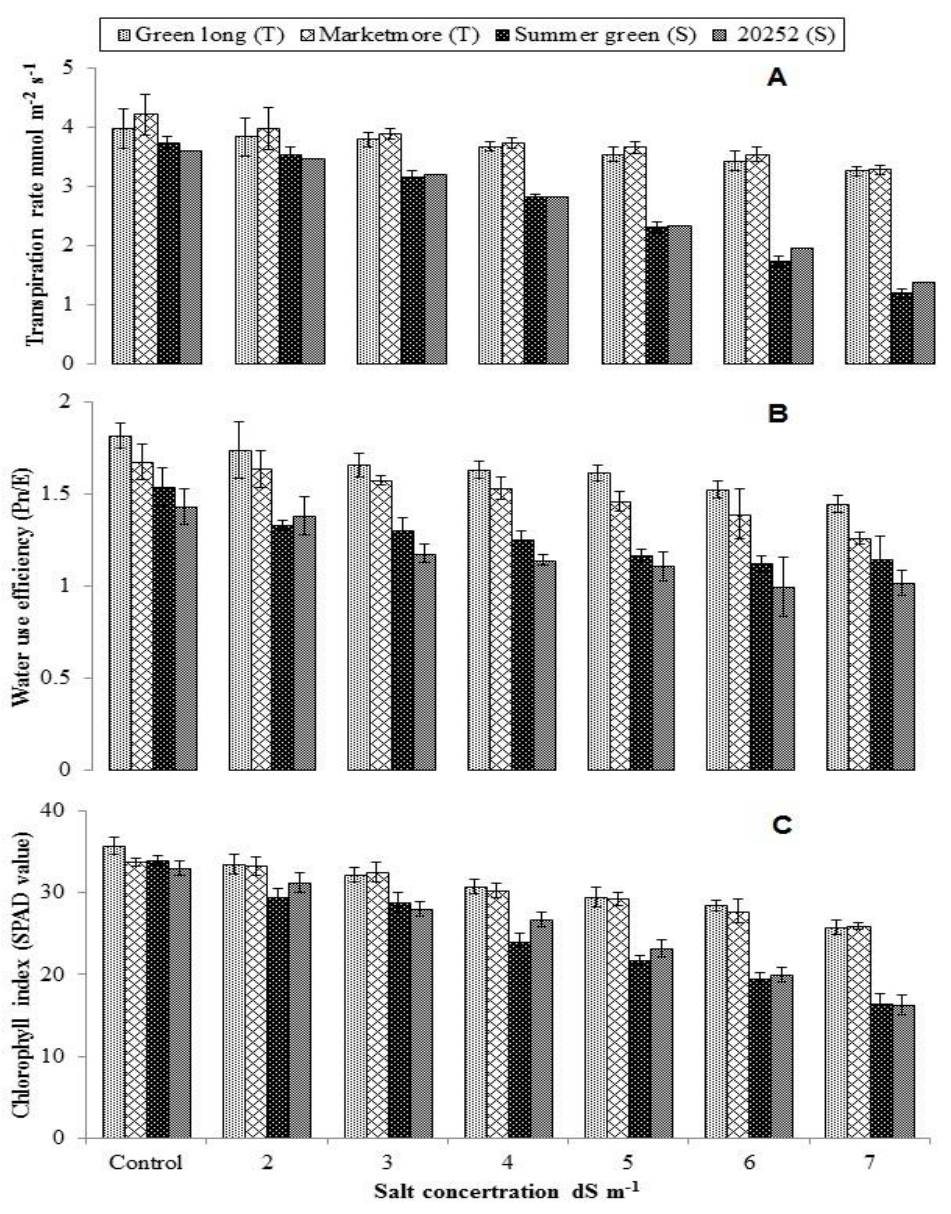

Figure 4. Effect of salt stress on (a) Transpiration rate (b) Water use efficiency (WUE) (Pn/E) (c) Chlorophyll contents

\section{Leaf inorganic osmolytes}

It is cleared from the results that rising levels of salinity modulated the concentration of in-organic osmolytes $\left(\mathrm{Na}^{+}, \mathrm{Cl}^{-}, \mathrm{K}^{+}\right.$, and $\left.\mathrm{Ca}^{+}\right)$in all cumcumber genotypes grown under salt stress (Table 1). Among the genotypes, 20252 and Summer green leaves had accumulated maximum contents of $\mathrm{Na}^{+}$and $\mathrm{Cl}^{-}$, respectively, whereas Marketmore showed least build up of $\mathrm{Na}^{+}$and $\mathrm{Cl}^{-}$contents in leaves in addition to improved 
deposition of ionic content of $\mathrm{K}$ and $\mathrm{Ca}$ that was followed by green long under all saline regimes. These outcomes showed that at $70 \mathrm{mM}$ level of salinity, cucumber genotypes Marketmore and Green long presented least increment in $\mathrm{Na}^{+}$and $\mathrm{Cl}^{-}$, however, Summer green and 20252 exhibited maximum accumulation of these ions which indicated that resistant genotypes had lowest level of $\mathrm{Na}^{+}$and $\mathrm{Cl}^{-}$in their leaves in comparison to sensitive cucumber genotypes. It can be concluded from the findings of this experiment is (Summer green or 20252) categorize as sensitive genotypes whereas, (Marketmore or Green long) are categorized as salt tolerant cucumber genotypes.

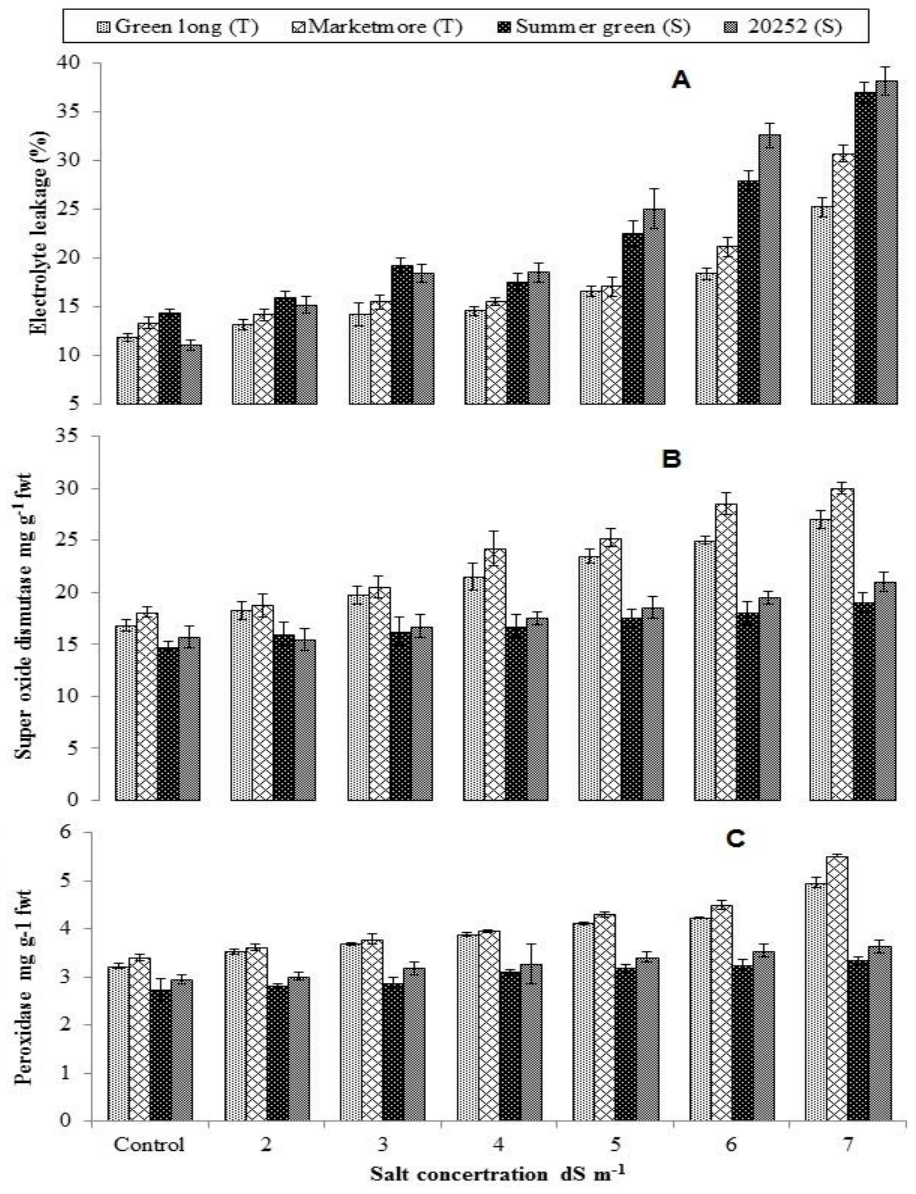

Figure 5. Effect of salt stress on leaf (a) Electrolyte leakage (\%) (b) Superoxide dismutase activity (c) Peroxidase activity

\section{Discussion}

Inhibition in plant growth and development is very usual phenomena under salinity stress (Ashraf et al., 2009; Mahboob et al., 2017; Sarwar et al., 2017). Results illustrated that salts significantly decreased the root/shoot length, their fresh/dry biomasses and number of leaves per plants in all studied cucumber genotypes (Figs. 1,2 and 3a). Under stressed condition variation in total number of leaves plant ${ }^{-1}$ is a important prevalence (Zhu et al., 2001). In present study, studied cucumber genotypes such as Marketmore and Green long was presented was little affected by salinity and presented maximum number of leaves while sumer green and 20252 failed to produce better number of 
leaves under saline conditions. Likewise reduction in leaves per plants were also observed by (Hassine and Lutts, 2010) in potato crop and (Bakht et al., 2011) in maize plant. Such decline in number of leaves in term of salt stress might be because of negative effects of salts on cell elongation mechanisms (Ashraf and Harris, 2004; Iqbal and Ashraf, 2005; Sawar et al., 2017).

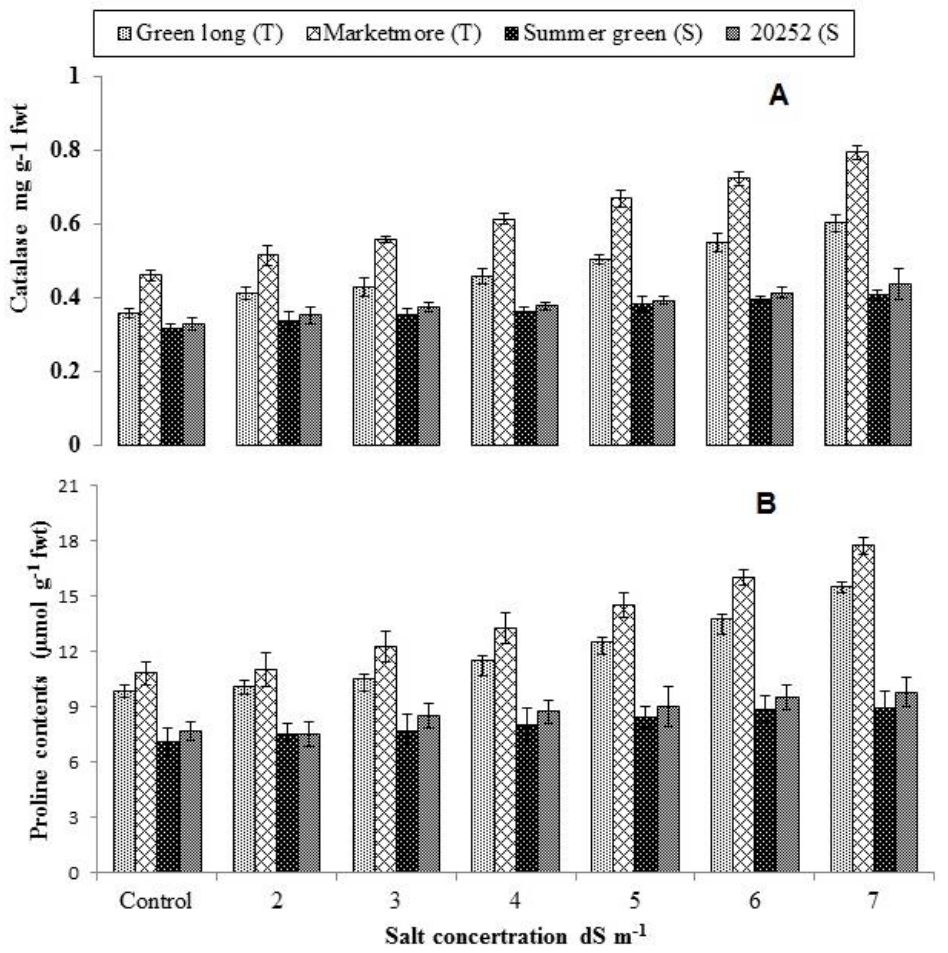

Figure 6. Effect of salt stress on leaf (a) Catalase activity (b) Proline contents

Table 1. Effect of salt stress on leaf inorganic osmolytes of four cucumber genotypes

\begin{tabular}{|c|c|c|c|c|c|c|c|c|}
\hline & \multicolumn{4}{|c|}{$N a^{+}$ions $\left(m g g^{-1} D . W\right)$} & \multicolumn{4}{|c|}{$K^{+} i o n s\left(m g g^{-1} D . W\right)$} \\
\hline $\begin{array}{c}\text { Salt } \\
\text { Treatments }\end{array}$ & $\begin{array}{c}\text { Green } \\
\text { long }\end{array}$ & Marketmore & $\begin{array}{c}\text { Summer } \\
\text { green }\end{array}$ & 20252 & $\begin{array}{c}\text { Green } \\
\text { long }\end{array}$ & Marketmore & $\begin{array}{c}\text { Summer } \\
\text { green }\end{array}$ & 20252 \\
\hline Control & $8.79 \pm 0.28$ & $3.46 \pm 0.45$ & $8.95 \pm 0.30$ & $10.00 \pm 0.43$ & $28.5 \pm 0.64$ & .91 & $28.75 \pm 0.85$ & $28 \pm 0.91$ \\
\hline $2.0 \mathrm{dS} \mathrm{m}^{-1}$ & $9.54 \pm 0.62$ & $9.26 \pm 0.90$ & $11.61 \pm 0.47$ & $14.23 \pm 0.69$ & $26.25 \pm 1.25$ & $27.25 \pm 1.2$ & $26.25 \pm 1.10$ & $25 \pm 1.08$ \\
\hline $3.0 \mathrm{dS} \mathrm{m}^{-1}$ & $11.19 \pm 0.42$ & $10.66 \pm 1.0$ & $15.76 \pm 0.82$ & $17.77 \pm 0.96$ & $24.25 \pm 1.10$ & $25.75 \pm 1.2$ & $24.25 \pm 1.10$ & $23.5 \pm 1.19$ \\
\hline $4.0 \mathrm{dS} \mathrm{m}^{-1}$ & $12.91 \pm 0.51$ & $11.27 \pm 0.60$ & $18.19 \pm 1.61$ & $20.66 \pm 1.68$ & $22.75 \pm 0.85$ & $24.75 \pm 1.3$ & $23 \pm 0.912$ & $22 \pm 0.91$ \\
\hline $5.0 \mathrm{dS} \mathrm{m}^{-1}$ & $15.89 \pm 0.57$ & $12.27 \pm 0.98$ & $23 \pm 1.164$ & $23.27 \pm$ & $20.75 \pm 0.85$ & $22.75 \pm 0.85$ & $19.75 \pm 0.75$ & $21.5 \pm 1.75$ \\
\hline $6.0 \mathrm{dS} \mathrm{m}^{-1}$ & $9.81 \pm 0.68$ & $15.69 \pm 2.06$ & $24.45 \pm 1.54$ & $28.14 \pm$ & $19.5 \pm 0.645$ & 21.75 & $15.75 \pm 0.85$ & $14.25 \pm 1.54$ \\
\hline $7.0 \mathrm{dS} \mathrm{m}^{-1}$ & 72 & $20.99 \pm 0.84$ & $32.35 \pm 1.38$ & 37.0 & 18.75 & $21 \pm 0.91$ & $13.5 \pm 0.64$ & 11.5 \\
\hline $\begin{array}{c}\text { Salt } \\
\text { Treatments }\end{array}$ & \multicolumn{4}{|c|}{$C a^{+}$ions $\left(m g g^{-1}\right.$ D.W $)$} & \multicolumn{4}{|c|}{$C l$ ions $\left(m g g^{-1}\right.$ D.W $)$} \\
\hline Control & $26.5 \pm 0.95$ & $29.75 \pm 1.10$ & $26.75 \pm 1.31$ & $28.75 \pm 1.2$ & $4.90 \pm 0.27$ & $4.27 \pm 0.15$ & $6.7 \pm 0.48$ & $4.6 \pm 0.49$ \\
\hline $2.0 \mathrm{dS} \mathrm{m}^{-1}$ & $24.75 \pm 0.85$ & $29 \pm 0.40$ & $25.25 \pm 1.3$ & $25.75 \pm 0.85$ & $5.32 \pm 0.30$ & $4.45 \pm 0.41$ & $8.11 \pm 0.48$ & $5.85 \pm 0.60$ \\
\hline $3.0 \mathrm{dS} \mathrm{m}^{-1}$ & $23.25 \pm 0.62$ & $27.75 \pm 1.10$ & $23.5 \pm 1.19$ & $23.75 \pm 1.79$ & $6.04 \pm 0.30$ & $5.20 \pm 0.38$ & $9.3 \pm 0.87$ & $5.99 \pm 0.58$ \\
\hline $4.0 \mathrm{dS} \mathrm{m}^{-1}$ & $22.75 \pm 0.85$ & $26.5 \pm 0.64$ & $20.75 \pm 0.85$ & $20.5 \pm 1.93$ & $6.62 \pm 0.75$ & $6.092 \pm 0.56$ & $11.60 \pm 1.03$ & $8.30 \pm 0.70$ \\
\hline $5.0 \mathrm{dS} \mathrm{m}^{-1}$ & $21.25 \pm 0.47$ & $25.25 \pm 0.85$ & $17.5 \pm 1.19$ & $18.25 \pm 0.85$ & $8.45 \pm 0.58$ & $7.12 \pm 0.61$ & $14.53 \pm 1.71$ & $9.44 \pm 0.82$ \\
\hline $6.0 \mathrm{dS} \mathrm{m}^{-1}$ & $20.5 \pm 1.32$ & $23.75 \pm 1.4$ & $15 \pm 1.47$ & $16.5 \pm 1.70$ & $9.4 \pm 0.47$ & $7.975 \pm 0.54$ & $16.31 \pm 1.66$ & $11.07 \pm 1.55$ \\
\hline $7.0 \mathrm{dS} \mathrm{m}^{-1}$ & $19.5 \pm 0.64$ & $22.75 \pm 0.85$ & $12.5 \pm 1.5$ & $12 \pm 1.22$ & $11.16 \pm 0.62$ & $8.89 \pm 0.75$ & $20.94 \pm 0.65$ & $15.96 \pm 1.31$ \\
\hline
\end{tabular}

Data represent the means $\pm \mathrm{SE}$ of four repeats. Means having different letters are significantly different at $\mathrm{P} \leq 0.05$ according to HSD Tucky Test 
The tested cucumber genotypes showed significant decreased in plant fresh and dry biomasses on exposure to various levels of salinity (Fig. 2), which established by the results of Mahboob et al. (2016) in Triticum aestivum (Noreen and Ashraf, 2008; Ashraf, 2009; Sarwar et al., 2016) in sunflower. However, under salt stress reduction in plant biomass might be due to lot of factors e.g, lack of turgor potential maintenance, sodium and chloride ions toxicity and variabilities in metabolic pathways. In the meantime, such factors disturb the gas exchange attributes that is ultimatelly cause decline in the activity of photosynthetic pigments (Sarwar et al., 2017). Subsequently, in this investigation reduction in plant biomass was due to decline in photosynthesis rate and a strong positive correlation was observed amongst dry weight of plants and gas exchange traits which revealed that those genotypes attained maximum dry biomass had higher rates of $g s$ and $P n$. The present results explained that photosynthesis was reduced due to maximum level of $\mathrm{Na}^{+}$or $\mathrm{Cl}^{-}$ions in plant cell which exhilarated the lethal impact on physiological mechanisms and functioning of leaf stomata. Bano (2010) also finds the same decreased in gas exchange traits in rice, when its exposed to saline stress. Results revealed that "Marketmore and Green long" presented lowest decreased in Pn and $g s$ as compared to "Summer green and 20252", thus these attributes can be used as a screening tool for the salinity tolerance in cucumber plants. The previous researchers reported that the saline stress induced significant differences in $g s P n$ and $E$ in sunflowers, rice and olive and these types of physiological traits can be measured as a potential signs of salinity tolerance (Nishimura et al., 2011). Since, salt stress have great impact on stomata function by losing the turgidity of guard cells ultimatelly it reduced transpiration rate in cucumber plants (Stepin and Klobus, 2006). Our findings are in agreement to Tezara et al. (2002), they described that sunflower showed a significant reduction in $E$ on exposure to water stress. On the other hand, salts stress restrict the availability of various essentials nutrients to plants especially $\mathrm{K}^{+}$ions (Najafi et al., 2007; Mahboob et al., 2013) and $\mathrm{K}^{+}$is responsible for guard cell turgidity (Burman et al., 2003) so under salinity, variabilities in guard cell functioning may be reduced $g s$ and $E$ in cucumber plants. Those cucumber genotypes which keep the constant transpiration rate and stomatal conductance under stressed environments were successful to regulate them osmotically through production of glycinebetaine and proline. Thus, it is clear that Marketmore and Green long genotypes of cucumber have salt tolerance potential due to higher production of proline in plant cell. Increase in production of such osmoprotectant under salinity reported that for Seepweed and Glasswort by Moghaieb et al. (2004), in Maiz by Hajlaoui et al. (2010) and Mahboob et al. (2013). In this study, reduction in chlorophyll contentsdue to substitution of $\mathrm{Mg}^{2+}$ ions by toxic $\mathrm{Na}^{+}$ions, that caused the denaturation of chlorophyll. Under salinity in cotton crop same results were reported by Meloni et al. (2003) and in Maiz stated by Mahboob et al. (2013). In literature a positive relationship was observed amongst chlorophyll contents production and plant biomass growth. It is showed that salinity fragmented the cell membranes to a smaller extent in resistant genotypes in comparison to sensitives. In genotypes Marketmore and Green long were showed the sign of little electrolyte leakage; might be tolerant genotypes presented lower $\mathrm{H}_{2} \mathrm{O}_{2}$ and least (EL) than sensitives, this trait electrolyte leakage can be used to determine the saline stress damage's and potential of tolerance in plants. Likewise, Noreen and Ashraf (2009) complied different cucumber genotypes to many salt concentrations and observed a increment in $\mathrm{LPO}$ and $\mathrm{H}_{2} \mathrm{O}_{2}$ level with various salt concentrations. Higher activities of SOD, POD and CAT detoxify the (ROS) in plant cell (Sekmen et al., 2012). So, salt tolerance potential is connected with the production 
of antioxidant enzymes activities (Balal et al., 2012). Same findings were comparised in this study a constant activities of antioxidant in tolerant cucumber genotypes with high potassium and calcium ions in their leaves, in results higher plant biomass, maximum photosynthesis activities as comparison to sensitive genotypes. As a result $\mathrm{K}^{+}$and $\mathrm{Ca}^{+}$ ions concentrations can used as a screening parameter for the estimation of salt stress tolerance in cucumber cultivars. Conclusion of this findings is that saline stress had negative impact on the growth and yield of cucumber plant and potential of salinity tolerance is greatly connected with the quantity of proline contents and $\mathrm{Ca}^{+}, \mathrm{K}^{+}$ions that play vital part in osmotic adjustment under salinity.

\section{Conclusions}

Salt stress harmfully affect the morpho-physiological and biochemical traits of cucumber genotypes by producing osmotic stress, ionic toxicity, altered stomatal functioning, impaired photosynthesis and restricted $\mathrm{K}^{+}$availability. Salt resistant cucumber genotypes were able to avoid most of the harmful implications of salt stress by $\mathrm{Na}^{+}$exclusion and maintenance of favorable levels of $\mathrm{K}^{+}$and $\mathrm{Ca}^{2+}$ that helped stabilize photosynthetic pigments and photosynthetic machinery under salinity stress resulting in comparatively better functioning and growth than salt sensitive genotypes. These cucumber genotypes can also serve for future studies dealing with salinity tolerance in cucumber, besides their worth in breeding programs and cultivation on soils where salinity seems inevitable

\section{REFERENCES}

[1] Ashraf, M., Haris, P. J. C. (2004): Potential biochemical indicators of salinity tolerance in plants. - Plant Science 166: 3-16.

[2] Ashraf, M., Rahmatullah, A. R., Bhatti, A. S., Afzal, M., Sarwar, A., Maqsood, M. A., Kanwal, S. (2010): Amelioration of Salt Stress in Sugarcane (Saccharum officinarum L.) by Supplying Potassium and Silicon in Hydroponics. - Pedosphere 20: 153-162.

[3] Bakht, J., Shafi, M., Jamal, Y., Sher, H. (2011): Response of maize (Zea mays L.) to seed priming with $\mathrm{NaCl}$ and salinity stress. - Spanish Journal of Agricultural Research 9: 252261.

[4] Balal, R. M., Khan, M. M., Shahid, M. A., Mattson, N. S., Abbas, T., Ashfaq, M., GarciaSanchez, F., Ghazanfer, U., Gimeno, V., Iqbal, Z. (2012): Comparative studies on the physio-biochemical, enzymatic, and ionic modifications in salt tolerant and salt sensitive citrus rootstocks under $\mathrm{NaCl}$ stress. - Journal of the American Society for Horticultural Science 137: 1-10.

[5] Bano, A. (2010): Root-to-shoot signal transduction in rice under salt stress. - Pakistan Journal of Botany 42: 329-339.

[6] Bates, L. S., Waldron, R. P., Teaxe, W. I. (1973): Rapid determination of free proline for water stress studies. - Plant and Soil 39: 205-207.

[7] Burman, U., Garg, B. K., Kathju, S. (2003): Water relations, photosynthesis and nitrogen metabolism of Indian mustard (Brassica jucea) grown under salt and water stress. Journal of Plant Biology 30: 55-60.

[8] Chance, M., Maehly, A. C. (1955): Assay of catalases and peroxidases. - Methods in Enzymology 2: 764-817.

[9] Chartzoulakis, K. S. (1992): Effects of $\mathrm{NaCl}$ salinity on germination, growth and yield of greenhouse cucumber. - Journal of Horticultural Science 67: 115-119. 
[10] Dogan, M., Tipirdamaz, R., Demir, Y. (2010): Salt resistance of tomato species grown in sand culture. - Plant, Soil and Environment 56: 499-507.

[11] Dorota, Z. (1997): Irrigating with high salinity water. - Bulletin 322 Agricultural and Biological Engineering Dep; Florida Cooperative Extension service Institute of Food and Agriculture Sciences University of Florida.

[12] El-Shraiy, A. M., Mostafa, M. A., Zaghlool, S. A., Shehata, S. A. M. (2011): Alleviation of Salt Injury of Cucumber Plant by Grafting onto Salt Tolerance Rootstock. - Australian Journal of Basic and Applied Sciences 5(10): 1414-1423.

[13] FAO. (2012): The State of the World's Land and Water Resources for Food and Agriculture (SOLAW) managing systems at risk. - Food and Agriculture Organization of the United Nations, Rome and Earthscan, London.

[14] Garcia-Sanchez, F., Jifon, J. L., Carvaial, M., Syvertsen, M. (2002): Gas exchange, chlorophyll and nutrient contents in relation to $\mathrm{Na}^{+}$and $\mathrm{Cl}^{-}$accumulation in 'Sunburst' mandarin grafted on different rootstocks. - Plant Science 162: 705-712.

[15] Giannopolitis, C. N., Ries, S. K. (1977): Superoxide dismutase I. Occurrence in higher plants. - Plant Physiology 59: 309-314.

[16] Gopalan, C., Rama, S. B. V., Balasubramanian, S. C. (1989): Nutritive value of Indian foods. - National Institute of Nutrition, Indian Council of Medical Research.

[17] Grattan, S. R., Grieve, C. M. (1992): Mineral element acquisition and growth response of plants grown in saline environment. - Agriculture Ecosystems \& Environment 38: 275300.

[18] Grieve, C. M., Gratan, S. R. (1983): Rapid assay for the determination of water soluble quaternary ammonium compounds. - Plant and Soil 70: 303-307.

[19] Hajlaoui, H., Ayeb, N. E., Garrec, J. P., Denden, V. (2010): Differential effects of salt stress on osmotic adjustment and solutes allocation on the basis of root and leaf tissue senescence of two silage maize (Zea mays L.) varieties. - Industrial Crops and Products 31: 122-130.

[20] Hasegawa, P. M., Bressnan, R. A., Zhu, J. K., Bohnert, H. J. (2000): Plant cellular and molecular responses to high salinity. - Annual Review of Plant Physiology and Plant Mololecular Biology 51: 463-499.

[21] Hassine, A. B., Lutts, S. (2010): Differential responses of saltbush Atriplex halimus L. exposed to salinity and water stress in relation to senescing hormones abscisic acid and ethylene. - Journal of Plant Physiology 167: 1448-1456.

[22] Heidari, M. (2010): Nucleic acid metabolism, proline concentration and antioxidants enzyme activity in canola (Brassica nupus L.) under salinity stress. - Agricultural Sciences in China 9: 504-511.

[23] Iqbal, M., Ashraf, M. (2005): Changes in growth photosynthetic activity and ionic relations in spring wheat. - Plant Growth Regulator 60: 41-52.

[24] Khan, W., Prithiviraj, B., Smith, P. (2003): Photosynthetic responses of corn and soybean to foliar application of salicylates. - Journal of Plant Physiology 20: 1-8.

[25] Lloyd, J., Kriedmann, P. E., Aspinall, D. (1989): Comperative sensitivity of prior lisbon lemon and valencia orange trees to foliar sodium and chloride concentrations. - Plant, Cell \& Environment 12: 529-540.

[26] Lutts, S., Kinet, J. M., Bouharmont, J. (1996): NaCl-induced senescence in leaves of rice (Oryza sativa L.) cultivars differing in salinity resistance. - Annals Bot 78: 389-398.

[27] Maeda, Y., Nakazawa, R. (2008): Effects of the timing of calcium application on the alleviation of salt stress in the maize, tall fescue, and reed canary grass seedlings. Biologia Plantarum 52: 153-156.

[28] Mahboob, W., Rehman, H., Basra, S. M. A., Afzal, I., Abbas, M. A., Naeem, M., Sarwar, M. (2015): Seed Priming Improves the Performance of Late Sown Spring Maiz (Zea mays) through better Crop Stand and Physiological Attributes. - Int. J. Agric. Biol 17(3): 491-498. 
[29] Mahboob, W., Khan, M. A., Shirazi, M. U. (2016): Induction of salt tolerance in wheat (Triticum aestivum L.) seedlings through exogenous application of proline. - Pak. J. Bot 48(3): 861-867.

[30] Mahboob, W., Khan, M. A., Shirazi, M. U. (2017): Characterization of Salt Tolerant Wheat (Triticum aestivum) Genotypes on the Basis of Physiological Attributes. - Int. J. Agric. Biol 19: 726-734.

[31] McCord, J. M. (2000): The evolution of free redicals and oxidative stress. - The American Journal of Medicine 108: 652-659.

[32] Meloni, D. A., Oliva, M. A., Martinez, C. A., Cambraia, J. (2003): Photosynthesis and activity of superoxide dismutase, peroxidase and glutathione reductase in cotton under salt stress. - Environmental and Experimental Botany 49: 69-76.

[33] Misra, A. N., Sahu, S. M., Misra, M., Singh, P., Meera, I., Das, N., Kar, M., Shau, P. (1997): Sodium chloride induced changes in leaf growth, and pigment and protein contents in two rice cultivars. - Biologia Plantarum 39: 257-262.

[34] Moghaieb, R. E. A., Saneoka, H., Fujita, K. (2004): Effect of salinity on osmotic adjustment, glycinebetaine accumulation and the betaine aldehyde dehydrogenase gene expression in two halophytic plants, Salicornia europaea and Suaeda maritima. - Plant Science 166: 1345-1349.

[35] Murphy, K. S. T., Durako, M. J. (2003): Physiological effects of short term salinity changes on Ruppia maritima. - Aquatic Botany 75: 293-309.

[36] Najafi, F., Khavari-Nejad, R. A., Rastgar-Jazii, F., Sticklen, M. (2007): Growth and some physiological attributes of pea (Pisum sativum L.) as affected by salinity. - Pakistan Journal of Biology 10: 2752-2755.

[37] Nishimura, T., Cha-um, S., Takagaki, M., Ohyama, K., Kirdmanee, C. (2011): Survival percentage, photosynthetic abilities and growth characters of two indica rice (Oryza sativa L. spp. indica) cultivars in response to isosmotic stress. - Spanish Journal of Agricultural Research 9: 262-270.

[38] Noreen, S., Ashraf, M. (2008): Alleviation of adverse effects of salt stress on sunflower (Helianthus annuus L.) by exogenous application of salicylic acid: growth andphotosynthesis. - Pakistan Journal of Botany 40: 1657-1663.

[39] Noreen, Z., Ashraf, M. (2009): Assessment of variation in antioxidative defense system in salt- treated pea (Pisum sativum) cultivars and its putative use as salinity tolerance markers. - Journal of Plant Physiology 166: 1764-1774.

[40] Qin, J., Dong, W. Y., He, K. N., Yu, Y., Tan, G. D., Han, L., Dong, M., Zhang, Y. Y., Zhang, D., Li, Z. A., Wang, Z. L. (2010): NaCl salinity-induced changes in water status, ion contents and photosyn thetic properties of Shepherdia argentea (Pursh) Nutt. seedlings. - Plant, Soil and Environment 56: 325-332.

[41] Sarwar, M., Amjad, M., Ayyub, C. M., Ashraf, A., Tehseen, S., Manan, A., Butt, M., Hussain, T., Nawaz, M. A. (2016): Evaluation of cucumber germplasm for salinity tolerance based on early growth attributes and leaf inorganic osmolytes. - Transylvanian review 24: 1077-1086.

[42] Sarwar, M., Amjad, M., Ayyub, C. M. (2017): Alleviation of Salt stress in cucumber (Cucumis sativus L.) through seed priming with triacontanol. - International Journal of Agricultural Biology 19: 771-778.

[43] Sarwar, M., Anjum, S., Khan, M. A., Haider, M. S., Ali, S., Naseem, M. K. (2018): Assessment of sustainable and eco-friendly agricultural substrates for eminence production of chilies for kitchen gardening. - Int J Recycl Org Waste Agriculture 7: 365374.

[44] Sekmen, A. H., Turkan, I., Tanyolac, Z. O., Ozfidan, C., Dinc, A. (2012): Different antioxidant defense responses to salt stress during germination and vegetative stages of endemic halophyte Gypsophila oblanceolata Bark. - Environmental and Experimental Botany 77: 63-76. 
[45] Sheekh-EL, M. M., Omar, H. H. (2002): Effect of high salt stress on growth and fatty acids content of the unicellular green algae Chlorella vulgaris. - Journal of Microbiology 55: 181-191.

[46] Stepien, P., Klobus, G. (2006): Water relations and photosynthesis in Cucumis sativus L. leaves under salt stress. - Biologia Plantarum 50: 610-616.

[47] Tezara, W., Mitchell, V., Driscoll, S. P., Lawlor, D. W. (2002): Effects of water deficit and its interaction with $\mathrm{CO}_{2}$ supply on the biochemistry and physiology of photosynthesis in sun flower. - Journal of Experimental Botany 53: 1781-1791.

[48] Yamaguchi, T., Blumwald, E. (2005): Developing salt-tolerant crop plants: challenges and opportunities. - Trends in Plant Science 10: 616-619.

[49] Yang, C. W., Wang, P., Li, C. Y., Shi, D. C., Wang, D. L. (2008): Comparison of effects of salt and alkali stresses on the growth and photosynthesis of wheat. - Photosynthetica 46: 107-114.

[50] Zhu, J. K. (2001): Plant salt tolerance. - Trends in Plant Science 6: 66-72. 